\title{
PERAN PENDEKTAN KONSELING BERBASIS DIALECTICAL BEHAVIOR THERAPY (DBT) DALAM MENDUKUNG PEMULIHAN TRAUMA PADA PEREMPUAN YANG MENGALAMI KDRT
}

\author{
Diana Christina $^{1}$, Irwanto Irwanto ${ }^{2}$ \\ ${ }^{1}$ Faculty of Psychology, Atma Jaya Catholic University of Indonesia \\ E-mail: diana_2016004014@univ.atmajaya.ac.id \\ ${ }^{2}$ Faculty of Psychology, Atma Jaya Catholic University of Indonesia \\ Email: irwanto_i@yahoo.com
}

Masuk :12-04-2019, revisi: 09-09-2019, diterima untuk diterbitkan :09-09-2019

\begin{abstract}
ABSTRAK
Kekerasan dalam rumah tangga mengacu pada segala bentuk perilaku semena-mena yang tidak hanya berupa kekerasan fisik, tetapi juga kekerasan verbal dan seksual. Kekerasan dalam rumah tangga adalah sebuah fenomena yang telah menarik perhatian dunia karena perilaku kasar yang diterima perempuan dari pasangannya dalam jangka panjang, yang mengarah pada konsekuensi buruk kesehatan mental seperti PTSD dalam bentuk pikiran yang mengganggu, mimpi buruk, kilas balik, hypervigilances, dan emosi-emosi negatif berlebih (kesedihan, kemarahan, kekecewaan, keputusasaan) yang dapat menyebabkan pikiran untuk bunuh diri. Dua wanita yang mengalami kekerasan dalam rumah tangga dan saat ini tinggal di tempat penampungan berpartisipasi dalam penelitian ini. Mereka diberikan teknik konseling berbasis Dialectical Behavior Therapy (DBT) untuk membantu mereka menerima pengalaman mereka tanpa dihakimi dan untuk meningkatkan kapasitas mereka untuk mengendalikan pikiran dan emosi mereka. Konseling berbasis DBT diberikan dalam tiga sesi; toleransi terhadap tekanan, mindfulness, dan regulasi emosi. Kami melibatkan dua peserta perempuan yang diberi tempat tinggal sementara. Screening menggunakan Beck Depression Index (BDI-II) yang menunjukkan setidaknya tingkat depresi menengah atas, dan checklist tentang jenis kekerasan, dampak fisik dan psikologis yang disebabkan oleh perilaku pasangannya yang kasar. Setelah tiga sesi konseling berbasis DBT, peserta mulai mendapatkan kendali atas hidup mereka, menunjukkan peningkatan dalam kepercayaan diri dan menjunjung tinggi keyakinan bahwa mereka dapat maju.
\end{abstract}

Kata Kunci: kekerasan dalam rumah tangga, terapi perilaku dialektik, wanita, trauma

\begin{abstract}
Domestic violence refers to any kind of abusive behavior that is not only physical, but also verbal and sexual violence. Domestic violence is a phenomenon that has garnered the worldwide attention due to the long term abusive behaviors that women have received from their partners, which leads to serious mental health consequences such as PTSD in the forms of intrusive thought, nightmares, flashback, hypervigilances, and overwhelming negative emotions (sadness, anger, disappointment, hopelessness) that may lead to suicidal thoughts. Two women who experienced domestic abuse and currently living in a shelter particiated in this study. They were provided with a counseling technique based on (DBT) to help them accept their experiences without any judgement and to enhance their capacity to controlling their thoughts and emotion. Counseling based on DBT was given in three sessions; distress tolerance, mindfulness, and emotion regulation. We involved two female participants who were provided with a temporary shelter. Screening using a Beck Depression Index (BDI-II) showed at least moderate depression level and above, and a checklist form about the type of violence, physical and psychological impact caused by their abusive partner's behavior. After three sessions of counseling based on DBT, participants started to gain control of their lives, show improvements in self-confidence and uphold a belief that they can move forward.
\end{abstract}

Keywords: domestic violence, dialectical behavior therapy, women, trauma.

\section{Introduction}

Domestic violence is a phenomenon that has garnered worldwide attention because of its relation to human rights and quality of life on an individual, both physically and psychologically. So far, we've been convinced that domestic violence is more prevalent in less educated, and low social economic societies. However, domestic violence actually has no specific pattern of characteristic 
about the abuser. In Indonesia, Komisi Nasional Perempuan (KOMNAS Perempuan) recorded that the number of reporting cases for domestic violence is increasing year by year, but the reports that they have received are just the tip of iceberg. It means, they are still so many women who are become the victims of domestic violence but have no courage to speak up. ${ }^{21}$

Domestic violence in Indonesia is more complex because it can't be separated from the patriarchal culture that is still believed by the community. They believe that the man should be the backbone of the family. Therefore, without their husband, it is not only embarrassing for the woman, but they also become powerless under the belief that women usually only do the household work and have no any income. As a woman, they believe that woman should be less dominant, and be the one submissive to the man. The false beliefs that are still believed by most of the people make a lot of women still become a victim of domestic violence and received torture or persecution that they should not have received.

According to Barnish (2004) women who are the victims of domestic violence, experience several psychological stages. In the early stages, some women usually react to abuse with shock and disbelief, they would make a rationalization by convincing themselves that it was just an accident, or not even consider their partner's action as an act of violence. They think they deserved to be treated like that as a punishment because they do something wrong. When the abuse becomes something that more often to happen, women start to develop coping strategies to deal with it. They often preserve hope that one day their husband will realized and they will have a better relationship. Some of them start to blame themselves and try to meet the expectations from their partner.

Furthermore, Barnish believed that women are more likely find a strategy in order to make them feel safer. When the violence becomes more unpredictable, the tendency of depression and demoralization are more likely to occur. This stage is a vulnerable stage for women due to the risk of them try to overcome their problem by using drugs and alcohol to suppress their feelings. When the tensions are high, and they are no longer have the ability to control the situation, some of them will develop an idea that staying with the abusive partner is better than going out and having nowhere to go. This idea leads to how women make many excuses and justification about what their partner did to them.

After several moments, one day they will realize that the relation that they've been working on for several years is not a relationship that they are expected. The redefining the relationship give them a chance to see the reality as it is and indirectly increase their self-worth. They eventually have the more courage to step out from the unhealthy relationship. Some of them convinced themselves to have a divorce and live separately from their abusive partner. The recovery stage is not only important but also high risk. Therefore, accompaniment from a therapist is suggested as a prevention because they are still vulnerable and at the risk of destructive behavior such as the addiction tendency, or self-harming because they can't manage their thought negative emotion about the traumatic experience that they've been through.

By understanding the process of how women perceived the traumatic experience, that they are tends to develop symptoms related to trauma disorder such as, feeling hopelessness, hyperarousal, dissociation, flashbacks, avoidance, depression, and also negative emotions such as sadness, anger, helplessness, and unworthiness. The psychological impact that caused by traumatic experience make women should be provided with some skills that might be useful in their emergency situation, when they have a flashback in the middle of the night, or the moment 
when they can't control their thought by thinking about the past traumatic experience and feel terribly upset because that moment they have no power to fight back.

Dialectical behavior therapy (DBT) is a method developed by Marsha Linehan by focusing on right here right now experience and acceptance. At first, DBT is intended for people with Borderline Personality Disorder (BPD) who have suicidal tendencies and self-harming. But recently, DBT is also effective to help not only BPD patients, but also several psychological problems such as domestic violence victim who are overwhelmed with their negative emotions. DBT has four basics and important skills, which are: (1) distress tolerance, (2) mindfulness, (3) emotion regulation, and (4) interpersonal effectiveness. In this study, we are focus on three skills that they can practice in their daily life.

From distress tolerance skills, we expect participants have a better way to regulate their negative emotions by using distress tolerance techniques. In mindfulness, participants try to focus on right here right now moment so they can be more present in the present moment, instead of focusing on The all three skills are complement to each other in order to achieve one goal of DBT, that they can accept their situation without any judgment. By giving them counseling based on DBT we expect them to have a better coping skill to help them recover from traumatic experiences.

\section{Method}

The research method used in this study is applied research because we try to give an immediate response in order to solve the current problem either it has already happened in a community, to prevent, or to fix (Miller, 2007) ${ }^{26}$ According to how we gather information, this research can be categorized as a qualitative research in order to capture and try to communicate something from the data that we have gained from participant (Patton, 2002).

The aim of this research is not only try do describe about the psychological impact from the domestic violence but also provide some skills that can reduce their emotional suffering from the domestic violence. The sampling technique that we used in this study is criterion sampling to confirm that researcher will gain the rich information and have a fully understanding about the problems that are perceived by the participants.

This study involved two participants that are characterized by: (1) women with experiences of domestic violence at least one year, (2) the trauma experienced caused some problems such as insomnia, frequent flashback, nightmares, lack of appetite, and any psychological conflicts that caused by the traumatic experiences. Participants are obtained from a shelter in Jakarta, who are given a temporary home to women and children of violence victim.

Screening participants were collected by administrating BDI-II that has been adapted to Indonesian verse, and psychological assessment by using BAUM and DAP to check if there is any potential risk that may put their life in danger. Before completing any assessment required, all participants had agreed to participate in this study by completing informed consent forms.

We also use an interview schedule that is also has been adapted from IPV (Intimate Partner Violence) questionnaire, ABI (Abusive Behavior Inventory), and psychological symptoms form stress - acute stress disorder based on DSM V. ${ }^{29}$ The type of question that we used mostly are open question in order to give some chances to the participants to express their thought and emotion. 
According to Yin (2011) analysis data in qualitative research usually has five stages; (1) compiling, (2) disassembling, (3) reassembling, (4) interpreting, (5) concluding. First, we gather and try to sort information that we have, and then we give label and code in order to classify the data. Then, we interpret the data by arranging new narration which can lead to make a summarizing and answering the research question that we have arranged from the beginning.

The counseling based on DBT module also has been checked by Dr. Sr. Anke Felicitas Böckenforde as the expert judgement to make sure that intervention module is suitable to be applied for women of domestic violence victim. The counseling is divided into three sessions, with each session lasting about $30-40$ minutes. All three sessions are given to obtain one main goal which is to facilitate women to have a better coping skills strategies while they start to gather their lives back together. When they can have a more adaptable coping strategies to manage their thoughts and negative emotions, we expect them to be able to increase their self-esteem and can empower their inner sources.

This study also has been reviewed and approved by the Institute of Research and Community Service (IRCS) with references number: 1354/III/LPPM-PM.10.05/10/2018. By gaining the approval by IRCS, this study has considered to ensure that this study does not bring any danger to participants.

\section{Results and Discussion}

From this study that involving two participants, the result showed there are several similarities and differences. First, in accordance with the explanation from Barnish, the violence that has been going on for years make them feel unworthy and the women start to believe that what happened to them is a thing that cannot be changed. Even though they feel unworthy and powerless, it still need to be consider the presence of children indirectly bringing hope and make them feel that they are important for somebody.

Second, apparently both of participants showed the several symptoms of trauma. A violence behavior that they have received make them unconsciously develop a simultaneously flight response and caused anxiety towards the abuser. They built a schema in their mind that the person who abused her unpredictably do something that might hurt them. The constant fear that experienced by participants lead to put them at the higher risk to develop anxiety disorder, or any disorder related to stress and trauma.

Third, we found out that the both participants have almost the same pattern that the intrusive thoughts and flashbacks are more often during the night when they were less active. In response to this problem, the DBT based counseling playing an important role to help the participants. The exercises from DBT is learn to control their mind by focusing at right here right now experience. They are practicing to clear their mind and focus on a thing. By keep practicing they will make a new healthier way to face their problem.

After three sessions of counseling, the confidence of participants gradually raised. They started to believe in themselves. Step by step convinced themselves that they are capable enough to start a new live by thinking and planning about what they can do to optimalize the inner resources. Even though, we still need to evaluate the program that we have made. 
We found out that the most common disturbance that appeared in both participants are lack of sleep, flashback, thinking about the past experiences, and helplessness feeling. So far all the negative moods and symptoms are met with several criteria of trauma caused by domestic violence. The intensity or the depth of emotions and intrusive thought seems to be influenced by the intensity of how severe the torture that they have received from their partner.

Related to the research instruments that have been used in this study BDI-II and questionnaire still limited on type of violence, frequency, and potency of stress and trauma related disorder. Regarding to this topic, the more-in depth study by involving more participants to participate in this topic research might enriching our data especially if there is any personality factors that may affect the trauma intensity and the DBT effectiveness as a method to help women have a better coping strategies to manage their thoughts and negative emotions.

\section{Conclusion and Recommendation}

Based on the findings in this study, negative experiences like domestic violence will bring trauma, both physically and psychologically. Psychological trauma that happened gradually. The accumulation of incapability to manage negative emotions will potentially lead to more serious psychological problem such as acute stress disorder, depression, PTSD, moreover tendencies of self-harming because the hopelessness feeling to deal with their problem.

We found out that even this study is more alike a personal problem, we still need to be aware of any potential issues that might occur in the participant's surroundings such as children, relatives, friends that might be effected by this personal problem.

The results of this study are expected to provide a module that has been adapted and adjust to meet the needs of women, domestic violence victim. From the three counselling sessions, we found out that one of participant is able to think more clearly and starting to put things together back in life. She started to find concrete ideas about her ability to manage finances, and gradually began to dare entering the healthier environment such as learning something new to enriching herself so she's no longer depend on his husband income.

This study has several limitations. First, this study involved limited number of participants, therefore, it is difficult to determine what kind of personality that might be the most suitable for DBT. Second, the point of view of this study is still limited focusing on the overwhelming emotions but emotion itself is something that can't be separated with cognition. A traumatic experience lead to cognitive distortion that can affect how people think about something, and perceived things differently.

So far, the module that has been designed for domestic violence victims is applicable and easy to apply because the materials that the we use are easy to obtain in every household. We also adjust some skills and activities that are more common to be applied in Indonesia. But since the alternative of activities need to adapt to due limited of available tools in the shelter, it makes them have very limited alternative activities.

Therefore, for further studies, we suggest to have more various activities so they have more chance to choose what kind of activity that might be the most suitable and comfortable for them. We are also need to be consider the fact that some participants will get bored for repeating the same exercise. The more various activities gave them chance to develop themselves by doing any kind of exercises that may be useful for them. Even so, the counselor who would like to apply this method should have a certification or at least under supervision by the certified on 
DBT in order to prevent any potential mistreatment which can affects the welfare of the participants.

\section{Acknowledgement.}

Thank you to the participants and parties who have been involved in this research, as well as those who support the writing of this scientific work.

\section{References}

Sodikin A. Survei BPS: Satu dari Tiga Perempuan Indonesia Pernah Jadi Korban Kekerasan. Available from: https://nasional.kompas.com/read/2017/04/05/07100021/survei.bps.satu.dari.tiga.perem puan.indonesia.pernah.jadi.korban.kekerasan

Altawian RS. The Impact of Domestic Violence on the Psychological Functioning of Saudi Arabian Female Students Studying in the United States A Dissertation Submitted to the Faculty of the Graduate School of in partial fulfillment of the requirements for the degree of. Proquest. 2016;(December).

Association AP. Trauma [Internet]. American Psychological Association. American Psychological Association; 2018 [cited 2018Nov24]. Available from: https://www.apa.org/topics/trauma/

Blasco-ros C, Sánchez-lorente S, Martinez M. Recovery from depressive symptoms, state anxiety and post-traumatic stress disorder in women exposed to physical and psychological , but not to psychological intimate partner violence alone: A longitudinal study. BMC

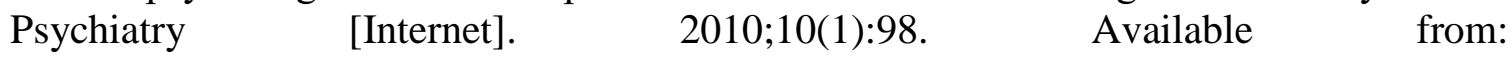
http://www.biomedcentral.com/1471-244X/10/98

Chetwin A. A review of the effectiveness of interventions for adult victims and children exposed to family violence Prepared for the Ministry of Social Development. 2013;(July).

DeJoghe ES, Bogat GA, Levendosky AA von EA. Women survivors of intimate partner violence and post-traumatic stress disorder : Prediction and prevention. 2008;54(4):294-300.

Lestari S. KDRT tertinggi dalam kekerasan atas perempuan di Indonesia - BBC News Indonesia [Internet]. BBC News. BBC Indonesia; 2017 [cited 2019Feb25]. Available from: http://www.bbc.com/indonesia/indonesia-39180341

Fitira E. Kekerasan pada Perempuan Selama 2017 Didominasi KDRT dan Pelecehan [Internet]. detiknews. Detiknews; 2018 [cited 2018Jun28]. Available from: https://news.detik.com/berita/d-3903861/kekerasan-pada-perempuan-selama-2017didominasi-kdrt-dan-pelecehan

Hansen NB, Eriksen SB, Elklit A. Effects of an intervention program for female victims of intimate partner violence on psychological symptoms and perceived social support. Eur J Psychotraumatol [Internet]. 2014;1:1-10. Available from: https://www.ncbi.nlm.nih.gov/pmc/articles/PMC4163755/pdf/EJPT-5-24797.pdf

Hawley S. Australian takes up fight against Indonesia's deadly domestic violence taboo [Internet]. ABC News. Australian Broadcasting Corporation; 2016 [cited 2019Feb25]. Available from: http://www.abc.net.au/news/2016-10-27/australian-expat-collecting-indonesiandomestic-violence-data/7968524

Howard LM, Trevellion K, Khalifeh H, Woodall A, Agnew-Davies R, Feder G. Domestic violence and severe psychiatric disorders: Prevalence and interventions. [Internet]. American Psychological Association. American Psychological Association; 2010 [cited 2019Jul27]. Available from: https://psycnet.apa.org/record/2010-10691-001 
Kolibonso RS. Kekerasan Dalam Rumah Tangga [Internet]. Kekerasan Dalam Rumah Tangga. Perkumpulan Bantuan Hukum Kalimantan; 2010 [cited 2018Jun26]. Available from: http://www.pbhk.org/kekerasan-dalam-rumah-tangga/

Komisi Nasional Anti Kekerasan Terhadap Perempuan. Peta Kekerasan Pengalaman Perempuan Indonesia. Jakarta, Indonesia: KOMNAS Perempuan; 2002.

KOMNAS Perempuan. Catatan Tahunan (CATAHU) Komnas Perempuan Tahun 2017 [Internet]. Labirin Kekerasan Terhadap Perempuan. KOMNAS Perempuan; 2017 [cited 2018Jun28]. Available from:https://www.komnasperempuan.go.id/reads-catatan-tahunan-kekerasanterhadap-perempuan-2017.pdf

KOMNAS Perempuan. Catatan Tahunan (CATAHU) Komnas Perempuan Tahun 2018 [Internet]. Tergerusnya Ruang Aman Perempuan dalam Pusaran Politik Populisme. KOMNAS Perempuan; 2018 [cited 2018Jun28]. Available from: https://www.komnasperempuan.go.id/file/pdf_file/2018/SIARAN PERS 2018/Lembar Fakta Catahu 7 Maret 2018.pdf

Linehan MM. DBT Skills Training Manual. 2nd ed. New York: The Guilford Press; 2015.

Miller SA. Developmental Research Methods. 3rd ed. United States of America: Sage Publication, Inc; 2007.

Patton MQ. Qualitataive Research and Evaluation Methods. 3rd ed. United States of America: Sage Publication, Inc; 2002.

Schauer M, Neuner F, Elber T. Narrative Exposure Therapy: a short-term intervention for traumatic stress disorder after war, terror, or torture. Cambridge, United States of America: Hogrefe; 2005.

Trauma, Mental Health and Domestic Violence [no year]. English. Florida Coalition Against Domestic Violence; [cited 2018Jun28]. Available from: https://www.fcadv.org/projectsprograms/trauma-mental-health-and-domestic-violence

U.S. National Library of Medicine. Domestic Violence in the 1970s - Circulating Now from NLM [Internet]. U.S. National Library of Medicine. National Institutes of Health; 2015 [cited 2018Jun26]. Available from: https://circulatingnow.nlm.nih.gov/2015/10/15/domesticviolence-in-the-1970s/

World Health Organization. Understanding and addressing violence against women Intimate partner violence. World Health Organization. 2012; WHO/RHR/12:1-12.

World Health Organization. Violence against women; 2017 [cited 2019Jun28]. Available from: http://www.who.int/news-room/fact-sheets/detail/violence-against-women 